\title{
COOPERATIVE LEARNING STRATEGY IN CRITICAL READING ENGLISH TEXT THROUGH TEAM GAME TOURNAMENT (TGT) AND JENGA
}

\author{
Fuzi Fauziyah $^{1}$, Siti Gina Meilani ${ }^{2}$, and Salsabila ${ }^{3}$ \\ fuzifau@gmail.com ${ }^{1}$ \\ ginameilani.11@gmail.com ${ }^{2}$ \\ Salsabilamasyhuri@gmail.com ${ }^{3}$ \\ Suryakancana University
}

\begin{abstract}
The rapid development of information has the potential to spread negative content such as hoax news, hate speech, or issues of radicalism and intolerance. In this case, critical reading skills are needed. By reading critically, readers can become more objective, able to sort and not easily swayed. However, the learning implementation of critical reading is not easy, especially coupled with the students' low reading interest and ability, especially towards English reading texts. This narrative review aims to examine cooperative learning strategies in critical reading of English texts through Team Game Tournament (TGT) and Jenga. The method used is literature study by examining various sources from journal articles in various databases, proceedings and official websites on critical reading, cooperative learning, TGT, and Jenga games. The selected data is then reduced, classified, analyzed, and concluded. The results of literature search show that in critical reading students not only understand the content of the text, but also analyze and evaluate the text they read. In practice, Jenga which is believed to have the superiority of cooperative, communicative, and effective aspects can be used by modifying and adding questions related to critical reading so that students try to understand and analyze the text accurately. Seeing the advantages of TGT as a cooperative learning strategy and the benefits of the Jenga in critical reading, the integration between the two can facilitate three important aspects, namely critical, fast and accurate so that it has the potential to develop students' critical reading skill in reading English text.
\end{abstract}

Keywords: critical reading, cooperative learning, team game tournament (TGT), jenga 


\section{INTRODUCTION}

Indonesia experiences a very high potential risk of spreading negative content such as hoax news, hate speech, or issues of radicalism and intolerance, this is a result of the low reading interest of the Indonesian people (Muyassaroh, 2019) and the ability to think critically which is still low (Rachmedita, Sinaga \& Pujiati, 2017) which certainly has the potential to break the unity and integrity of the Indonesian nation. In fact, an aspect that should be considered to interpret the information is having reading ability (Kurniawati, Komariah, Maolida, \& Salsabila, 2018). To overcome this problem, critical reading skills are one of the most important needs.

In critical reading, readers not only understand what they read but also are able to judge the truth of the information conveyed by the author. In line with this idea, Bloom (quoted in Sudarwati \& Manipuspika, 2016) states that there are three levels in critical reading, namely analysis, synthesis, and evaluation. At the level of analysis, the reader distinguishes fact from opinion, propaganda and reasoning errors. The reader identifies the reasons for something happening, assesses the qualifications of the source of the information, and determines the evidence to support the conclusion, then the reader draws the conclusion. At the synthesis level, the reader collects information, makes predictions, and anticipates results, because more than one possible answer will be found. Finally, at the evaluation level the reader makes judgments by assessing ideas and solutions by providing opinions. From these statements it can be concluded that critical readers have special skills in asking, analyzing, and evaluating a reading, so that readers are able to distinguish between facts and opinions on a reading.

Critical reading skill is very beneficial for students (Riadi, 2015). By reading critically, students are able to reveal the information contained in the text using their own language, because critical readers do not only absorb what the writer reveals, but also think about the issues discussed and are able to analyze and provide assessments. Moreover, by having high level of reading ability impacts on students' writing ability itself, it is in accordance with Maolida and Mustika (2018) stated that the low level of reading causes of the low ability of students in writing. But in reality, there are still many students in Indonesia who are not yet able to read critically. Such as research conducted by Hayati, Atmazaki and Abdurrahman (2015) on class XI students of SMA Negeri 5 Padang. They revealed that the reading skill performed by students generally had not applied reading critically, but students only captured what was written in the reading, students read only to answer questions given by the teacher about the reading. If the teacher asks about response of the students to content of reading that has been read before, some students have difficulty expressing it again. 
Responding to this phenomenon, students need the ability to read critically so that they become objective, clever, and not swayed by the rapid development of information from within and outside the country. However, the application of critical reading learning is not easy, especially coupled with the students' low reading interest and reading ability, especially in English reading texts. Therefore, an alternative method is needed so that students can be more interested in learning to read critically, one of them is by using cooperative learning methods.

As stated by Wichadee 2004 (quoted in Pratama, 2013) cooperative learning can be one of effective ways to solve problems in classroom. This strategy creates a pleasant and comfortable environment for learning. It can also help students to study harder, and develop other skills such as learn how to cooperate with other peers. Furthermore, Nurhamidah (2014) states that cooperative learning is useful in improving students' comprehension of reading, this strategy can provides students with a learning atmosphere that is not threatening but fun, increases student participation in the process of learning, and increases student interaction and confidence as they can share knowledge each other.

One of the methods developed from cooperative learning is the Team Game Tournament (TGT). This method is a learning model focused on students' grouping consisted of 4-6 students with different academic achievement levels (Lestari, 2017). The TGT method is divided into three parts, namely: teams, games, and tournaments. In the team section, students are asked to make groups and each group discuss the material provided collaboratively. Furthermore, the game section contains questions or tasks related to the material discussed. This aims to test individual understanding of the material. And the last is tournaments, where the structure of the competition is carried out to complete games or tasks. Team members must answer questions to earn points for their own team.

In practice, TGT has an aspect of excitement that can be obtained from the rules of the game being carried out. In TGT, students try to make their group win by competing with other groups, so that students will feel responsible for it. Cooperative learning can be done by integrating game media. According to Abror's opinion (quoted in Aristin and Abidi, 2013) educational games as an innovative learning medium can be used to support teaching and learning activities and attract student learning interest. Therefore, this educational game can use Jenga as the medium.

Jenga is a game of physical and mental skills that contains 54 wooden blocks. This game is similar to the Uno Stacko game where the aim is to keep piling up the block towers higher until they collapse (Rules, 2009). Three blocks 
are arranged in a row to become one layer. The next layer is arranged transversely. This is done continuously until all layers are arranged into tower. The players of this game can be two players or more. With using one hand, the player takes turn to pick up a block of the tower without making it collapse, then its block must be put again on Jenga tower top.

In critical reading activities on English texts, Jenga games can be modified by adding a card consisting of several questions related to critical reading on each block. Each student as a player must take a piece of Jenga block in sequence. The player must follow the card instructions, then place a block on Jenga tower top without making it collapse. If the tower collapses, the team will get a penalty by deducting the points, and the team will get points if the answer is correct. This research is a literature study to explore cooperative learning strategies, Team Game Tournament (TGT) and Jenga games in critical reading of English text.

\section{METHOD}

The method used in this research is literature review by examining various sources related to critical reading, cooperative learning, team game tournament (TGT), and Jenga game. The results of these literature reviews will be used to identify cooperative learning strategies in critical reading of English texts through TGT and Jenga games. The type of data used by researchers is secondary data. Data is taken from several sources such as journal articles from various databases, proceedings and official websites. Then the data obtained were selected to be reduced, classified, analyzed, and concluded so that a comprehensive description was obtained regarding the application of cooperative learning, TGT, and Jenga in critical reading of English texts. The criteria used to select the journal to be taken are 1) Criteria for the completeness of articles and language, the selected articles are articles published in Indonesian and English which are written in intact (title, name of author, year, publisher/journal name, and bibliography) meanwhile one website that is used as a reference in this study is taken from the official website (About Jenga \& Uno Stacko Rules). 2) The criteria for novelty, journals and scientific articles selected are articles published maximal last 10 years. 3) Relevance criteria, the articles selected are articles that have keywords related to the title raised.

\section{FINDINGS AND DISCUSSION}

\section{Critical Reading}

Copyright C2021 JOEPALLT

Journal of English Pedagogy, Linguistics, Literature, and Teaching 
People know that more information is usually made in writing, whereas reading is the key to digging up information in writing. Reading is a very useful activity, because by reading someone can get much information from writing. This is in line with Astutik (2015) which states that reading is a cognitive process or an activity that tries to find much information in writing. This means that reading is an activity to understand the contents of the reading text through a thought process.

In reading activities, there are several types of reading, one of them is critical reading. Critical reading is defined as reading by looking at the author's motives and assessing those motives. Readers not only absorb what is there, but they together with the authors think about the issues being discussed (Soedarso cited in Diana, 2014). Furthermore, Giyatmi, Wijayava, \& Arumi (2020) stated that critical reading is one type of reading skill besides reading interpretation, literal reading, and creative reading so that a high level of understanding is needed in critical reading. Critical reading involves analysis, evaluation of a text. In other words, critical reading does not just understand the content of the text.

Mardiana, Maman, \& Sultan (2019) stated that critical reading is different from other types of reading. Critical reading is more effective because it can improve memory, encourage students to be more focused, \& evaluate the text they read. With this critical reading strategy, students are expected to improve the way of critical thinking, active, and creative in fostering a high sense of social and in the learning process in the classroom.

The difference between critical reading and other types of reading is that in critical reading activities, several aspects are required. Dewi (2016) stated that critical reading activities require three aspects, namely the first is the fast aspect, the second is the accurate aspect, and the third is the critical aspect. Speed in reading a text is defined as the fast aspect. The accurate aspect is the reader is able to analyze a text based on the level of irrelevance with untruth. The critical aspect is that the reader is able to accept the writer's thoughts from writing, truth, logic, or according to reality and reject what is untrue and baseless.

Critical reading has been used in various learning contexts. Several previous researchers have discussed the use of critical reading in a variety of different contexts, such as in expressing the implied meaning of short stories (Mardiana, Maman, \& Sultan, 2019), strengthening character education in higher education (Diana, 2014), reading comprehension of elementary school students (Yarfriaty, 2016), character development (Ati \& Widiyarto, 2019), and many other studies. Based on that thing, we know that critical reading can be applied in different learning contexts, it is not just focused on one learning context. 
In critical reading activities, previous researchers have also applied several techniques and strategies used in critical reading. Some of these techniques and strategies include Asco (Analyzing, Solving Problems, and Comparing) (Hariyati \& Septiana, 2019), the Know Want to Know Learned (KWL) strategy (Nurhayati, 2019), One Day One Page movement (Idammatussilmi, 2020), and the technique of reading SQ3R (Survey, Question, Read, and Recite). Several studies on the techniques and strategies used in critical reading give a deeper understanding that in learning critical reading various techniques and strategies can be applied, so that teachers and students can more enjoy the process of learning critical reading.

In the context of English learning, critical reading has also been used by several previous researchers in their research, such as research conducted by Giyatmi, Wijayava, and Arumi (2020), by using argumentation text as critical reading learning material for students of English Study Program, as well as research conducted by Lestari (2015) which examined the process of teaching critical reading in an EFL class at a public high school in Bandung and Albeckay (2014) in a Reading class in the context of higher education. Furthermore, the research conducted by Femilia (2018) was conducted to find out how good critical readers use their critical reading strategies and what reading models are shown by this strategy. Then Rohmah (2018) has also examined students' problems, strategies, and reflections in critical reading in fourth semester students in the EFL class.

From the discussion and results of these previous studies, we can conclude that critical reading can give positive impact for students, because critical reading activities make students do something more than just reading.

\section{Cooperative Learning Strategy}

In the learning process of critical reading, the teacher has the responsibility to choose learning methods and strategies that are suitable for students' conditions so that students do not get bored quickly while learning. This is in accordance with the opinion of Khori \& Ahmad (2019) which states that in teaching reading, the teacher is responsible for helping students to achieve learning goals, motivating students to read appropriate texts, designing useful assignments of reading, setting classroom procedures effectively, and creating supportive environment for practicing reading.

There are several strategies that can be implemented in terms of improving students' reading comprehension, one of them is the cooperative learning strategy. In the context of reading, Marzban \& Akbarnejad (2013) show that cooperative learning is proven to improve reading ability of English texts. Slavin as one of the 
developers of cooperative learning, identified it as a variation of teaching methods where the students are required to work each other in the smalls group in terms of learnin (Sudarwati \& Manipuspika, 2016). In cooperative learning, students learn together in groups, exchange ideas, and help each other in mastering the material being taught. Suprijono (2010) also states that cooperative learning motivates students to help each other and encourage each other in the learning process. This mutually influences the success in achieving learning goals, because according to Lisnawati's opinion (2016), if students want to be successful as a team, they will encourage their teammates to succeed.

Cooperative learning strategy consists of many techniques that can be applied to help, enhance and provide a more enjoyable atmosphere for students. According to Slavin (quoted in Adilla, 2017) the techniques are Teams Games Tournament (TGT), Cooperative Integrated Reading and Composition (CIRC Student's Team Achievement Division (STAD), Team Accelerated Instruction (TAI), and Jigsaw. These techniques, for example STAD and CIRC, can improve students' reading performance, even for texts that require deepening such as poetry (Ramadhanti \& Yanda 2017). Based on Johnson and Johnson (cited in Agustini, Marhhaeni \& Suarnajaya, 2013) who stated that there five basic elements of learning, such as: 1) Face-to-face interaction, students interact with another member to support each other, 2) Positive interdependence, students feel responsible for their group and their own job, 3) Group behavior, group members are required to be collaborative to work together, 4) Group processing, group members analyze their own and group's ability to work together, 5) Individual and group accountability, each student is responsible for doing their part of the task, and group is responsible for fulfilling its objectives.

Students' critical reading process can be facilitated through those five basic elements of cooperative learning. In fact, in accordance with the opinion of Devi, Mustafa \& Gustine (2015) cooperative learning promotes critical thinking through dialogic instruction in which students involve in dialogue by arguing on different points of view. Students have many opportunities to brainstorm their insights and ideas, express different viewpoints, synthesize different information and evaluate solutions. In addition, the discussion activity in cooperative groups also helps students to become better speaker, reader, listener, and writer. In this sense, cooperative learning has an important influence on the development of critical thinking (Devi et al., 2015). Students can improve their critical thinking when reading a text, and take responsibility for discussing their own learning material.

Each teaching method has its advantages and disadvantages. according to Suprijono (2010) cooperative learning has advantages, namely; a) students can be more motivated when they work in groups; b) hold students more responsibility 
for their learning; c) students are more actively involved in the learning process, thus making they enjoy it more; d) students can learn from each other the material in groups; e) improve students' communication skills. Further he also conveyed the shortcomings of this method, namely; a) does not perform well in every lesson; b) requires more time because it requires group discussion; c) creates a noisy and lively classroom atmosphere.

\section{Team Game Tournament (TGT)}

Team Game Tournament (TGT) is often used in learning in various contexts with the aim of involving students to be active and work together to increase grades in groups. Slavin (quoted in Rahmat, Suwatno \& Rasto, 2018) revealed that the cooperative learning form of TGT is an academic tournament through quizzes with score assessments, as students compete with other team members whose previous academic members as team leaders achievements are equal. The TGT model is used to improve student learning outcomes in class. Yudianto, Sumardi, \& Berman (2014) revealed that learning with the TGT cooperative game model allows students to learn to be more relaxed, foster a sense of responsibility, confidence, respect for others, discipline, competitive, sportsmanship, cooperation that involves all students in learning. . The TGT learning model has student center characteristics that focus on constructing student knowledge, as expressed by Slavin (quoted in Wardani, Syafri \& Delfi, 2015) where students are expected to find important information to construct their own knowledge.

According to Huda (quoted in Lisnawati, 2016) the goal of TGT focuses on creating an efficient classroom atmosphere in which students are actively engaged in the process of teaching and learning. Furthermore, Nur \& Wikandari (quoted in Juwita, Sari, \& Septianingrum, 2017) explained that TGT has been implemented in various subjects. The highest effectiveness is found in subjects whose learning objectives are sharply formulated with one correct answer. Lestari (2017) states that TGT is one of the methods developed from cooperative learning. A learning model that focuses on working with students at various academic levels achievement into the cooperating small teams consisting of 4-6 students with heterogeneous members. The TGT method is divided into three parts, namely: teams, games, and tournaments. In teams, students are asked to form groups and each group discuss the material provided collaboratively. In the game, contains questions or tasks related to the material discussed. It aims to test individual understanding of the material. Meanwhile, a tournament is a structure in which competition is carried out to complete a game or task. Team members have to answer questions to earn points for the home team. 
The types of TGT expressed in Wardani, Syafri \& Delfi (2015) can increase student motivation in reading, increase student competitiveness in answering questions and help each other for students who do not understand the material. In this analysis, the TGT model can improve student achievement. In the context of research conducted by Priatna, Tatang, \& Gusrayani (2017) learning to find information quickly from various special texts through reading and scanning with steps during the implementation of learning using the TGT method by providing material in class directly and discussions led by the teacher .

The TGT model is widely applied with various media, one of which is research conducted by Susana (2017) using domino card media. Where the material is arranged and designed in the form of games from the material presented to test the knowledge gained by each group. Most of the quiz questions are simple. Each student takes a card that is numbered and answers the questions that match the number on the card. Students that respond to the questions correctly will have a point It is this score that students will collect for the weekly tournament. In this context the application of the Team Game Tournament learning model uses the Jenga game media. Where each group maintains the structure of the jenga block and each member reads the questions contained in the block.

The description and components of the TGT method according to Slavin (quoted in Lestari, 2017):

a. Class presentation, at this stage the material is presented in class directly by the teacher. Thus students will attend seriously, because they realize it's going to benefit them, in answering the test, and the questions that were answered.

b. Teams, consisting of 4-6 students with different academic achievement levels. The main goal of the team is intended to ensure that all team members develop well and to train members in particular who are able to complete the quiz well. After the teacher presents the material, the team works on worksheets or other materials. Most often, studies take the form of students asking each other to make sure they understand what it is, or working on problems together and correcting misunderstandings if teammates make mistakes. Teams provide peer support for academic performance which is important for learning effects.

c. The game consists of questions whose contents are relevant and built to test the awareness of students learned from class presentations and teamwork implementation. 
d. Tournament, the formation in which the game played. Usually applied after the instructor gave a class presentation at the end of the week or unit and the team had completed the group assignment on the assignment sheet.

e. Team Recognition, the main concept of team recognition is calculating the progress of individuals and teams and providing certificates or other types of recognizing appreciation. Team recognition is granted to the champion which gets the tournament's best total. In addition, rewards are also given in the form of learning motivation

\section{Jenga as the Media}

Media is an inseparable part of the teaching and learning process in order to achieve the learning objectives. Arsyad 2017 (quoted in Prakoso \& Santosa, 2020) stated that learning media is something that can be used in delivering material in teaching and learning process in order to engage students' attention in learning. With the help of various media, learning will be more interesting, easy to understand, and learning outcomes more meaningful. Along with the times, nowadays many innovative learning media have emerged, one of which is learning media based on educational games.

Educational type games aim to provoke students' interest in learning about the subject matter while playing, so that with happy feelings it is hoped that students can easily understand presented material. One of the game-based learning media is Jenga. According to Sari (2017) Jenga is effective in attracting students' attention to make them focus on learning material. Jenga is a wooden block game consisting of 54 wooden blocks arranged to become a tower. Leslie Scott as the founder of this game, create this game in the early 1970's. The word Jenga comes from the Swahili language which means to build. Based on information from Jenga (2016) Jenga was introduced to the public in 1982 by the famous Harrod shopping center in London. Then, launched in North America in 1986, and has since become an international gaming icon.

To build a Jenga tower, the player first has to line three wooden blocks in a row, then the next layer is arranged transversely. This is done continuously until all layers are arranged into tower. The players of this game can be two players or more. With using one hand, the player takes turn to pick up a block of the tower without making it collapse, then its block must be put again on Jenga tower top.

The Jenga game is almost the same as the Uno Stacko block piling game, but the blocks in Uno Stacko are made of colored plastic. The Uno Stacko consists of 45 blocks with 5 colors, namely red, yellow, green, blue and purple. Copyright (C2021 JOEPALLT

Journal of English Pedagogy, Linguistics, Literature, and Teaching 
The goal of this game is the same as that of Jenga, which is to keep piling up the towers higher until they collapse. According to Rules (2009) when the tower falls, the game is over and the winner is the last person who manages to pull and replace the last block without causing the tower to fall.

Block-based games such as Jenga and Uno Stacko are proven to be able to help the learning process in the classroom. Based on the results of research conducted by Lestari \& Purwandari (2018), students who play the Uno Stacko game admit that they are happy to apply it in learning because they feel more relaxed and fun. So that students do not feel that there is difficulty receiving lessons because it is interspersed with the Uno Stacko game. In addition, Anggraini (2019) also argues that the Uno Stacko game is proven to be effective in improving students' understanding of English vocabulary. In addition, Sahathevan and Yamat (2020) found that Jenga blocks also allow students to learn English simple sentence construction optimally through fun learning, because the element of fun can minimize students' fear of making mistakes and feelings nervous during making sentences. From some of the descriptions of the research results above, it can be concluded that the use of game media to compile a tower of blocks can be implemented in all types of learning materials. This effectiveness depends on the teacher's creativity in modifying this game so that learning activities become more meaningful, including learning critical reading on English texts. Jenga game can be modified by adding a card consisting of several questions related to critical reading on each block. In addition, students will be divided into 6 groups. Each student as a player must take a piece of Jenga block in sequence. The player must follow the card instructions, then place a block on top of the Jenga tower without causing the Jenga tower to collapse, if the tower collapses, the team will get a penalty by deducting the points, and the team will get points if the answer is correct.

To make it more interesting, there will be other rules in this game; 1) there will be cards with bonus points if the player can answer the question correctly, and penalty points if the player states the wrong answer; 2) cards that allow the player to throw questions at the opposing team; 3 ) card which is allows players to ask other players to answer the correct answer; 4) a card that allows the player to skip a question and then take another chunk.

The modified Jenga game is proven to have advantages, according to Sari (2017) in his research that the modified Jenga is a learning media product that has several advantages, namely:

1) Cooperative Aspects. Because of Jenga is played in groups, the students can be more cooperative. They will help and work each other to understand the 
learning material conveyed through this game. The group will not become the winner if every student doesn't cooperative.

2) Communicative Aspects. Interaction and communication process occur when the students need to explain the learning material, convey the idea or opinion, and explain their answer to another student. So that every student is provoked to interact and communicate each other.

3) Affective Aspects. In playing this game, students are indirectly trained to have high empathy. If all students participate in this game, it will be going well and the learning material can be easily understood. Moreover, this successfulness can be achieved if students are not selfish, caring, and have the willingness to support each other in order to understand the learning material.

\section{Potential Integration of Cooperative Strategies through TGT with Jenga Games in Critical Reading}

Integration of learning methods and media is needed to achieve learning objectives. According to Nasution (2017) learning methods have an effect on improving student learning achievement, one of is which the achievement of the learning objectives achieved. In achieving learning objectives, not only methods, but media are also needed as expressed by Syastra (quoted in Tafonao, 2018) that learning media can make it easier for teachers to convey subject matter to students so that it makes it easier to achieve learning goals which have been specified. In this case, the cooperative strategy through the Team Game Tournament method can be integrated with Jenga media to improve the critical reading skills of English texts by taking into account the various advantages and benefits that are complementary to cooperation through TGT and Jenga media. In addition, the integration of TGT as a form of cooperative learning and the Jenga game fulfills the three necessary aspects of critical reading, namely fast, accurate and critical aspects.

In critical reading, there are three important aspects (quoted in Dewi, 2016), namely the fast aspect, in critical reading, reading speed is the difference between critical reading and other types of reading that rarely pay attention to the aspect of speed. The second is the accurate aspect, with the accurate aspect the reader is able to analyze the text they read based on the level of irrelevance and untruth. Then the third is the critical aspect, through the critical aspect the reader is able to accept the author's thoughts from writing, truth, logic, or according to reality and reject those that are untrue and baseless. In other words, critical reading is not just reading the text, but also the reader is required to analyze the text by paying attention to these three aspects. In relation to learning English, critical reading is suitable to be integrated in reading English texts, by referring to several techniques and strategies that have been proposed by previous researchers. 
Critical aspects of reading can be facilitated through cooperative learning. In this case, students learn together in groups to exchange ideas and help each other in mastering the material being taught. Suprijono (2010) states that cooperative learning motivates students to help each other and encourage each other in the learning process. This strategy can provide students with a pleasant learning atmosphere, so as to increase student participation in the learning process, and increase student interaction and confidence, because students can share and exchange knowledge together. In relation to improving reading comprehension, cooperative learning strategies have been shown to facilitate students' critical reading processes. In fact, in accordance with the opinion of Devi, Mustafa and Gustine (2015) cooperative learning promotes critical thinking through dialogical instruction where students engage in dialogue by expressing different points of view regarding the text being read. In addition, students exchange ideas about their ideas and insights, synthesize different information, and evaluate solutions. Furthermore, discussion activities in cooperative groups can also help students to become better listeners, speakers, readers and writers. Thus, it can be concluded that cooperative learning has a significant influence on the development of students' critical thinking in reading a text.

Besides the critical aspects, fast and accurate aspects of critical reading can be facilitated through the Team Games Tournament (TGT) as a cooperative learning method in which students are grouped into groups of four to five members in each group. Each group consists of heterogeneous student members. The game starts by answering questions from the given text. Each group of students competes by answering the questions appropriately, each individual student in the group takes turns answering questions to get a group score with the aim of understanding and analyzing the text to be balanced for each student member. Type of cooperative learning using TGT can facilitate students to be active and work together to increase scores in groups. So that it can encourage students to focus on critical reading and try to quickly understand and analyze text.

Fast and accurate aspect of critical reading can also be stimulated through a modified Jenga by attaching question cards related to critical reading on each block. Jenga is a game consisting of 54 wooden blocks arranged in such a way as to become a tower and this game will end when one of the players makes the tower collapse. The purposes of using Jenga is to provoke students' interest in learning in learning the subject matter while playing. So that it is hoped that the students can easily understand the subject matter being taught and try to answer questions accurately. When the game progresses, each student, as a player must take a piece of Jenga block in sequence. The player must follow the card instructions accurately, then place a block on top of Jenga tower without causing 
the Jenga tower of collapse, if it collapses, the team will get a penalty by deducting the point, and the team will get a point of the answer is correct. Furthermore, the modified Jenga game is proven to have advantages from several aspects, as revealed by Sari (2017), namely: 1) Cooperative aspect, the students can be more cooperative. They will help and work each other to understand the learning material conveyed through this game. 2) Communicative aspect, the interaction and the communication will be occur because every student is encouraged in doing that in a group. 3) Affective aspect, the successfulness of the game can be reached if the students in the group are not selfish, caring, and have the willingness to support each other in order to understand the learning material.

From the description above, it can be seen that the integration of the Team Game Tournament (TGT) as a cooperative learning strategy and Jenga games in critical reading of English texts complement each other to develop three aspects of critical reading skills, namely critical, fast and accurate aspects.

\section{CONCLUSION}

The results of this study indicate that in critical reading students do not only understand the content of the text, but also analyze and evaluate the text they read. Thus, students are able to judge the truth of the information submitted by the author by distinguishing between facts and / or opinions. In supporting the learning process of critical reading, cooperative learning is able to facilitate students to learn together in groups, provide many opportunities to exchange critical thoughts about their insights and ideas, express different points of view, synthesize different information and evaluate solutions. Meanwhile, Team Game Tournament (TGT) as one of the cooperative learning techniques has the advantage of making students work together in teams to improve group reading scores. In TGT, students try to make their group win by competing with other groups by answering questions related to the text quickly and accurately. Jenga, as a game media used in TGT, can be attached a card consisting of several questions related to critical reading on each block to make students answer critical reading questions quickly and accurately which also involves cooperative, communicative and affective aspects. Seeing the advantages of cooperative learning, TGT and Jenga games in critical reading, the integration between the three can facilitate three important aspects of critical reading, such as in a critical, fast and accurate way so that it has the potential to develop students' critical reading skills in reading English texts. 


\section{REFERENCES}

Agustini, N. M. S., Marhhaeni, A. A. I. N. \& Suarnajaya, I. W. (2013). The effect of cooperative learning techniques and students' attitude on the reading comprehension of the eleventh grade students of sman 1 kediri. E-Journal Program Pascasarjana Universitas Pendidikan Ganesha Program Studi Pendidikan Bahasa Inggris. 1.

Albeckay, E. M. (2014). Developing reading skills through critical reading programme amongst undergraduate efl students in libya. Procedia - Social and Behavioral Sciences, 123, 175-181.

Anggraini, D. R. (2019). The effectiveness of uno stacko game to improve student's mastery in learning vocabulary. (Skripsi). University of Negeri Semarang, Semarang.

Aristin, N. I. \& Abidin, Z. (2013). Penerapan pembelajaran tgt berbantuan game edukasi terhadap kemampuan pemecahan masalah siswa. Jurnal Kreano. 4(1), 50-56.

Astutik, R. (2015). Strategi pembelajaran kemampuan membaca kritis berdasarkan faktor membaca dan hasil tes kemampuan membaca kritis pada mahasiswa semester vi kelas a program studi pendidikan bahasa sastra indonesia universitas sanata dharma yogyakarta tahun ajaran 2015. (Skripsi). University of Sanata Dharma Yogyakarta, Yogyakarta.

Ati, A. P. \& Widiyarto, S. (2019). Pembinaan karakter melalui kegiatan membaca kritis pada siswa smp kota bekasi. MATAPPA: Jurnal Pengabdian Kepada Masyarakat. 2(1), 39-42.

Devi, A. P., Musthafa, B. \& Gustine, G. G. (2015). Using cooperative learning in teaching critical thinking in reading. English Review: Journal of English Education. 4(1), 1-14.

Dewi, S. R. (2016). Faktor kemampuan membaca kritis pada siswa kelas xi mia 2 di sma negeri 1 kasihan, bantul, yogyakarta tahun ajaran 2015/2016. (Skripsi). University of Sanata Dharma Yogyakarta, Yogyakarta.

Diana, P. Z. (2014). Teknik membaca sq3r dalam membaca kritis untuk penguatan pendidikan karakter di perguruan tinggi. CARAKA. 1(1), 31-40.

Femilia, P. S. (2018). Critical reading strategies employed by good critical readers of graduate students in elt. Tefla Journal. 1(1), 30-34.

Giyatmi, Wijayava, R. \& Arumi, S. (2020). Teks argumentasi sebagai materi pembelajaran membaca kritis (critical reading) pada mahasiswa program studi bahasa inggris. Proceeding of Implementasi Merdeka Belajar Berdasarkan Ajaran Tamansiswa National Seminar. Yogyakarta, Indonesia. p. 282-290.

Hariyati, N. R. \& Septiana, H. (2019). Implementasi asco (analyzing, solving problems, and comparing) terhadap pembelajaran membaca kritis. LITERASI. 10(2), 92-98. 
Hayati, N., Atmazaki \& Abdurrahman. (2015). Hubungan keterampilan membaca kritis dengan keterampilan menulis artikel populer berdasarkan gaya belajar siswa kelas xi sma negeri 5 padang. Jurnal Bahasa, Sastra dan Pembelajaran. 2(1), 38-48.

Idammatussilmi. (2020). Peningkatan kemampuan membaca kritis siswa mi najmul huda melalui gerakan one day one page. JIP (Jurnal Ilmiah PGMI). 6(1), 36-51.

Jenga. (2016). About jenga. Retreived from https://www.jenga.com/about.php

Khori, M. \& Ahmad, A. (2019). Enhancing students' reading comprehension through the collaboration between reciprocal teaching and cooperative learning. Advances in Social Science, Education and Humanities Research. 178, 574-577.

Lestari, D. \& Purwandari. (2018). Pengembangan permainan uno stacko sebagai media pembelajaran untuk meningkatkan kerja sama dan kemampuan berpikir kritis siswa pada materi kalor kelas xi tkr 1 smkn 1 jiwan. Proceeding of Quantum \#25 National Seminar. 27 Januari 2018, Yogyakarta, Indonesia. 145-149.

Lestari, Z. W. (2015). The teaching of critical reading in an efl classroom. PEOPLE: International Journal of Social Sciences. 1(1), 519-530.

Lisnawati, N. A. (2016). The use of teams games tournament (tgt) method to improve students' writing skill of descriptive text. (Skripsi). University of Islam Negeri Salatiga, Salatiga.

Kurniawati, N., Komariah, A., Maolida, E. H., \& Salsabila, V. A. (2018). Integrating multimodality and jigsaw reading in teaching reading comprehension to young learners. Journal of English Pedagogy, Linguistics, Literature, and Teaching, 6(2).

Maolida, E. H., \& Mustika, G. (2018). Students' writing process for project ibunka: A case study of EFL writers. Journal of English Language Teaching and Linguistics, 3(3), 203. https://doi.org/10.21462/jeltl.v3i3.147

Mardiana, Maman, M., \& Sultan. (2019). Membaca kritis dan kemampuan mengungkapkan makna tersirat teks cerpen siswa smp. Bahasa: Jurnal Keilmuan Pendidikan Bahasa Dan Sastra Indonesia. 1(3), 137-148.

Marzban, A., \& Akbarnejad, A. A. (2013). The effect of cooperative reading strategies on improving reading comprehension of iranian university students. Procedia: Social and Behavioral Sciences. 70, 936-942.

Nasution, M. K. (2017). Penggunaan metode pembelajaran dalam peningkatan hasil belajar siswa. STUDIA DIDAKTIKA: Jurnal Ilmiah Bidang Pendidikan. 11(1), 9-16.

Nurhamidah, I. (2014). Enhancing students' critical reading skills through group discussion in cooperative learning. Dinamika Bahasa Dan Ilmu Budaya. 9(2), 25-34. 
Nurhayati. (2019). Meningkatkan membaca kritis dalam pemahaman bacaan dengan strategi know want to know learned (kwl) siswa kelas x smkn 1 bangkinang. Jurnal Pendidikan Tambusai. 3(3), 1102-1112.

Palimbong, N. (2013). Penerapan model pembelajaran kooperatif tipe team games tournament (tgt) untuk meningkatkan hasil belajar siswa pada mata pelajaran pkn kelas xi ips 1 di sma negeri 1 solo. Edu Civic. 1(1).

Prakoso, P. S. \& Santosa, A. B. (2020). Pengembangan perangkat pembelajaran model pembelajaran kooperatif tipe tgt (teams games tournament) menggunakan permainan uno stacko pada mata pelajaran pemrograman , mikroprosesor \& mikrokontroler kelas xi tav smkn 1 blitar agus budi santosa. Jurnal Pendidikan Teknik Elektro. 9(2), 301-306.

Pratama, A. (2013). Using cooperative learning strategies to improve reading comprehension of the seventh grade students at smp $n 1$ borobudur in the academic year of 2012/2013. (Skripsi). University of Negeri Yogyakarta, Yogyakarta.

Priatna, Y. U., Tatang, D., \& Gusrayani, D. (2017). Penerapan metode teams games tournament dalam pembelajaran menemukan informasi secara cepat dari berbagai teks khusus melalui membaca memindai. Jurnal Pena Ilmiah. 2(1), 1531-1540.

Rachmedita, V., Sinaga, R. M. \& Pujiati. (2017). Peningkatan kemampuan berpikir kritis melalui penggunaan strategi active sharing knowledge. Jurnal Studi Sosial Program Pascasarjana P-IPS. 5(1).

Rahmat, F. L., Suwanto \& Rasto. (2018). Meningkatkan pemahaman konsep siswa melalui team games tournament. Sosio Didaktika: Social Science Education Journal. 5(1), 15-23.

Ramadhanti, D. \& Yanda, D. P. (2017). Understanding poetry through the use of cooperative learning model. Jurnal Cakrawala Pendidikan. 37(3), 436446.

Riadi, B. (2015). Kemampuan membaca kritis dengan menggunakan teknik sq3r mahasiswa program studi pendidikan bahasa dan sastra indonesia. AKSARA: Jurnal Bahasa Dan Sastra. 16(2).

Rohmah, E. A. \& Wahyudin. (2016). Pengaruh model pembelajaran kooperatif tipe teams games tournament (tgt) berbantuan media game online terhadap pemahaman konsep dan penalaran matematis siswa . EduHumaniora: Jurnal Pendidikan Dasar. 8(2), 126-143.

Rohmah, G. N. (2018). Critical reading: students' problems, strategies, and reflections. J-ELLiT(Journal of English Language, Literature, and Teaching). 2(1), 21-26.

Rules, U. (2009). Uno stacko rules. Retreived from https://www.unorules.com/uno-stacko/ 
Sahathevan, E. N. \& Yamat, H. (2020). Learning simple sentence construction using colourful jenga blocks. International Journal of Academic Research in Progressive Education and Development. 9(1), 1-14.

Sari, T. L. W. (2017). Development of accounting jenga as a learning media to improve students motivation in class xi ips 1 sma negeri 1 prambanan klaten academic year 2016/2017. (Thesis). National University of Yogyakarta, Yogyakarta.

Sudarwati, E. \& Manipuspika, Y. S. (2016). Cooperative learning strategy for improving students' critical reading ability: a case study in english study program of brawijaya university. EDUCARE: International Journal for Educational Studies. 9(1), 13-28.

Suprijono, A. (2010). Cooperative learning: teori \& aplikasi PAIKEM. Pustaka Pelajar. Indonesia.

Susanna. (2017). Penerapan teams games tournament (tgt) melalui media kartu domino pada materi minyak bumi siswa kelas xi man 4 aceh besar. Lantanida Journal. 5(2), 93-105.

Susilawaty \& Anwar, K. (2019). Implementasi model cooperative integrated reading and composition (circ), scramble dan teams game tournament (tgt) dalam meningkatkan. Proceeding of PS2DMP ULM National Seminar. $5(1)$.

Tafonao, T. (2018). Peranan media pembelajaran dalam meningkatkan minat belajar mahasiswa. Jurnal Komunikasi Pendidikan. 2(2), 103-114.

Wardani, F., Syafri, K. and Delfi, S. (2015). The use of team game tournament (tgt) to improve students' reading skill in narrative text on the first grade at sma n 4 pekanbaru. Jurnal Online Mahasiswa. 5(2),1-9.

Yarfriaty. (2016). Meningkatkan kemampuan membaca pemahaman siswa melalui metode membaca kritis pada siswa kelas v sd negeri 18 kampung pansur. Jurnal Konseling dan Pendidikan. 4(1), 122-129.

Yudianto, W., Sumardi, K. \& Berman, E. (2014). Model pembelajaran teams games tournament untuk meningkatkan hasil belajar siswa smk. Journal of Mechanical Engineering Education. 1(2).

Yudiasmini, N. K., Agung, A. G. \& Ujianti, P. R. (2014). Penerapan model pembelajaran kooperatif tipe teams games tournament (tgt) berbantuan media puzzle dalam meningkatkan perkembangan kognitif. e-Journal PGPAUD Universitas Pendidikan Ganesha. 2(1). 